\title{
Croatian Translations of Paradise Lost
}

\section{Abstract}

The article presents an overview and analysis of the five existing Croatian translations of John Milton's Paradise Lost, including two integral translations (Ivan Krizmanić, 1827; Mate Maras, 2013) and three partial ones (Pasko Antun Kazali, mid-19th century; Hugo Badalić, 1896-97; Antun Šoljan 1962, 1980). In addition to providing five diverse Croatian interpretations of Paradise Lost, an English and international classic, these five renderings reflect various tendencies and developments within Croatian literary culture and particularly those that affected its translation practices in different periods.

Keywords: John Milton, Paradise Lost, Croatian translations, Hugo Badalić, Pasko Antun Kazali, Ivan Krizmanić, Mate Maras, Antun Šoljan

In Croatian culture, John Milton is esteemed as an undisputed English, European, and world literary classic, even though he is not counted among the most popular and influential anglophone (canonical) authors, which include - first and foremost - William Shakespeare, followed by the classics such as G. G. Byron, E. A. Poe, T. S. Eliot, and others ${ }^{[1]}$ Accordingly, although his reception has been less intense and systematic in comparison with a number of other European cultures (see Duran et al.), it has progressed relatively steadily since its outset in the first half of the 19th century, which coincided both with the Romantic reappraisal of Milton and the proper beginning of the Croatian reception of English-language literatures (Filipović 9-10) ${ }^{[2]}$ The last decades of the 19th century saw the beginning of literary-critical interest in Milton, which has remained relatively modest so far, but has nonetheless played an important role in introducing Milton and his work to the Croatian audience. 
It is not surprising that Milton's celebrated retelling of the biblical story of the fall of man, the epic Paradise Lost, has proven to be the most popular part of his oeuvre, both from the scholarly and translational point of view. Apart from the translations of a number of shorter poems, scattered in poetry anthologies and literary magazines, there are currently five Croatian translations of Milton's epic - two integral translations and three partial ones. In other words, the image of Milton in Croatian culture is largely based on his epic masterpiece, which has primarily ensured him the status of a European and world classic, and this status was, again, featured as an important factor in the overall policy governing the Croatian translations of Paradise Lost ${ }^{[3]}$ This was already acknowledged by the first translator, Ivan Krizmanić, whose enterprise was motivated by the fact that, by that time (1827), Milton's text had been translated into "almost all European languages" (Krizmanić, Predgovor 10$)^{[4]}$

Although its two significant precursors in the genre of the religious epic, Dante's Divina commedia and Tasso's Gerusalemme liberata, have had a far greater impact on Croatian literature and culture, Paradise Lost has been related to several Croatian early modern biblical epics on the broader, generic level, albeit with an awareness of their denominational differences (Catholic vs. Milton's Protestant orientation). These texts include, for instance, Croatian Judita (1521) (Judith, 1991), and Latin Davidias (finished c. 1517) both written by the father of the Croatian Renaissance Marko Marulić (Slamnig 136), which, in fact, precede Milton's epic, as well as two other examples from the same (Baroque) period: Kristijada (1670) by another classic, Junije Palmotić (translation of Marco Girolamo Vida's Christias; Novak 369), and Ostan Božje ljubavi (1712) (The Spur of God's Love), by a lesser-known author, Andrija Vitaljić (Novak 688). In terms of its canonical status, Milton's epic has another analog here - the central Croatian Baroque epic Osman (composed by Ivan Gundulić in the 17th century), which was historical in content but also based on Christian values and was partly inspired by Tasso's Gerusalemme liberata (Warnke 168-69).

Moreover, Paradise Lost has been compared with the later and shorter biblical epic based on the story of creation - Prvi ljudi (1862) (First Humans), by the prominent Romanticist Petar Preradović. Even though some parts indicate possible direct contact with Milton's text, these similarities are minimal, and Preradović's text is of a narrower thematic focus and has a different philosophical and poetical background (Šrepel; Puhalo 327). 
Such general analogies and possible links could undoubtedly help familiarize the Croatian audience with Paradise Lost, even though they did not have a noteworthy impact on Croatian literature and culture. Nevertheless, it is the five translations that played the key role in its reception, which offered an overview not only of the diverse Croatian interpretations of Milton's epic as an English and international classic but also of the various tendencies and developments within Croatian literary culture and, in particular, those affecting its translation practices in different periods. Although some of them are still unknown, or at least inaccessible to the domestic readers, all five Croatian renderings of Paradise Lost can hence, in a more general sense, be viewed along the lines of Lawrence Venuti's notion of translation as "domesticating inscription," which "never communicates in an untroubled fashion because the translator negotiates the linguistic and cultural differences of the source text by reducing them and supplying another set of differences drawn from the receiving situation to enable the translation to circulate there" (Venuti 11). This fact was also emphasized by one of the five Croatian translators of Paradise Lost, Antun Šoljan, who proposed a similar definition of translation as "retelling," that is, an interpretation and reconstruction of the original text that inevitably furnishes it with the features of its new linguistic and literary context and does not essentially differ from the purportedly original forms of creative writing (Šoljan $119-48)^{[5]}$

All Croatian translations transformed Milton's text in their specific ways, but at the same time, they managed to transpose a number of its (key) features, albeit with varying degrees of success. Bearing in mind that there has been only one brief and incomplete overview of these translations so far (Strojan) ${ }^{[6]}$ and only two translations have been analyzed (Krizmanić's and Badalić's), ${ }^{[7]}$ this article will address each of these translations, with the aim to highlight some of the key aspects of translators' negotiations between Milton's original and the Croatian linguistic, literary, and cultural tradition, and thus hopefully prepare the ground for their potential further in-depth analysis. After briefly contextualizing these translations in Croatian literary and cultural history, the analysis will hence focus on the translator's general approach to the original verse form and the syntactic makeup of Milton's lines, as well as on its implications for the transposition of the original style and content. The two integral translations will also be examined with regard to the treatment of the 
historical, cultural, and literary references in Milton's epic, with particular emphasis on their relevant paratextual additions, that is, the translators' notes.

Each of the five renderings of Milton's epic occupies a specific place in Croatian literary and cultural history. The first, prose translation (entitled Raj zgubljen) was completed in 1827 (but published as late as 2005 in modern transcription) ${ }^{[8]}$ It emerged at the dawn of one of the defining periods in Croatian literary and cultural history, marked by the Croatian National Revival, which began in the 1830s and established the foundations of the modern Croatian language and literature. It's author, Ivan Krizmanić (1766-1852), a Catholic priest, writer, and a translator from several languages, as well as an important supporter of the Revival, was also a pioneer Croatian translator of a text by Shakespeare (a fragment from Romeo and Juliet; Lupić and Schubert). Krizmanić was well aware of the fact that his translation of Paradise Lost might never reach its audience, assuming his homeland was still not financially capable nor interested in such a publishing enterprise (Krizmanić, Predgovor 10). Croatian culture was then indeed in a difficult position and needed a few decades to consolidate; yet this would marginalize Krizmanić's text even more, as it was written in (what is now) the Kajkavian dialect of north-western Croatia, whereas the new and still current standard language was to be based on the more widely spread Shtokavian dialect, which Krizmanić himself later embraced (cf. Schubert 117-20). It should be borne in mind, on the other hand, that this translation grew out of the three-century-long linguistic and literary tradition, which had outgrown the boundaries of a mere regional dialect, enabling Kajkavian to develop into a stylized and supraregional literary language (Schubert 28-29). Reaching its zenith in the 17th and 18th centuries, this tradition still flourished in the early 19th century (Štebih Golub, "Kajkavski hrvatski književni jezik u 19. stoljeću” 113) and is nowadays being re-evaluated in Croatian scholarship, which adds new meaning and value to Krizmanić's Kajkavian version of Paradise Lost as well.

The fate of the second translation of Milton's epic has been even less fortunate. Possibly dating to the 1850s (Janković 225), it is almost unknown and still unpublished[9] Its author, Pasko Antun Kazali (1815-94), was also a priest, as well as a translator and a writer from Dubrovnik, who was well acquainted with European literature, especially the Romanticist literary trends. However, 
Kazali now similarly occupies a rather marginal position in Croatian literary history, partly due to his own specific idiom, which is basically Shtokavian, but interspersed with archaic and regional vocabulary, and might be as difficult to comprehend to modern readers as Krizmanić's. Kazali's work has also been (partly) re-evaluated in the last few decades, so that, among other things, he is now remembered as the first Croatian translator of (two) Shakespeare's entire plays from its originals (King Lear and Julius Caesar). The manuscript of his translation of Paradise Lost comprises three versions (entitled Raj izgubljen in one version and Raj izgubljeni in the remaining two), which render the entire first part and a fragment of the second book (1-2.237) ${ }^{[10]}$ Kazali's is a verse translation, but it domesticates Milton's text to a significant degree in its own way, particularly through the choice of the verse form - the so-called epic or asymmetrical decasyllable, originally used in oral epic poetry. Adopted in accordance with the (Pre)Romanticist reappraisal of folkloric tradition, it became a standard and neutral verse form during the 19th century and was regularly employed in written poetry and translation (Kravar 94-95). Still, some of its original folkloric undertones often remained perceptible, and Kazali's translation was no exception to this.

While it can be presumed that Kazali may have originally intended to translate the entire Paradise Lost, the two following translations were intentionally fragmentary and aimed to present only some of its illustrative segments to the Croatian audience. Hence, they even focused on the same wellknown episodes from Milton's epic (but not exactly the same lines): the opening (Book 1) and the temptation scene (Book 9). The first translation, rendering the original lines 1.1-81 and 9.494-792, is the work of a relatively minor Croatian poet and translator, Hugo Badalić (1851-1900), who is also known as a translator of a play by Shakespeare (Coriolanus, albeit from German). His translation of Paradise Lost (entitled in accordance with the modern standard Croatian, same as the two succeeding translations, Izgubljeni raj) was first published in the magazine Pobratim in 1896-97 and reprinted in 1903, in the first Croatian anthology of English language literatures (Dukat, Čitanka 103-13) [11] $^{[1}$ The next translation appeared in 1962, penned by Antun Šoljan (1932-93), a renowned 20th-century literary figure and a prolific translator from a number of languages, English in particular (including, again, Shakespeare, and numerous other classics as well as Šoljan's contemporaries). His selection of lines from Paradise Lost (1.50-124, 9.679-732) was first published in his well-known anthology Sto najvećih djela svjetske književnosti (The 
Hundred Greatest Works of World Literature $!^{[12]}$ Both Badalić and Šoljan used the Croatian equivalent of the original verse form, although in somewhat different manners and contexts, which will be analyzed in more detail below.

The last existing translation of Paradise Lost appeared relatively recently, in 2013. Its author is another eminent and prolific translator from several languages, Mate Maras (1939), whose most important achievements include, among others, the translation of the complete works of William Shakespeare (2006-07). Parts of his translation of Paradise Lost first appeared in literary magazines in 2008, which marked the 400th anniversary of Milton's birth (Maras, "Pohrvaćivanje"), and the integral translation was also published in an edition that symbolically confirmed Milton's canonical status - the series Vrhovi svjetske književnosti (Summits of World Literature). It was accompanied by an expert afterword (Brlek) and received the prestigious publishing award Kiklop the following year. Maras, too, opted for a verse translation, although not for the iambic pentameter, but a free verse form of varying length and aiming at an underlying iambic intonation (Maras, "Notes" 9 [no. 1]). Adopting an approach similar to that in his translation of Shakespeare's works, he thus decided to abandon the earlier tradition of transposing the iambic pentameter into its equivalent Croatian form and devised an individual solution ${ }^{[13]}$ for reasons that will merit further mention in the following section.

The two translators who abandoned any (specific) verse form - Krizmanić and Maras - could focus more intently on the transposition of content and this undoubtedly made it easier for them to translate Paradise Lost in its entirety. Ivan Krizmanić explicitly emphasized his intention to faithfully adhere to the original content as much as possible, criticizing the two earlier European translators whose versions he was familiar with (S. G. Bürde and J. Delille) for their modifications of Milton's text (Krizmanić, Predgovor 10). Maras similarly justified his choice of verse form in an earlier comment on the then ongoing translation process (Maras, "Pohrvaćivanje"), referring to the common problems associated with the transposition of English iambic pentameter lines into Croatian, which often requires condensation of content and/or increase in line number, as a single English line can in general accommodate more words due to their lower average length (Kravar 76; Engelsfeld, Hrvatski prevoditelji 80). He therefore believed that a more flexible line would help him 
avoid "mutilating" the original and abide by the principle of line-for-line translation, while aiming to achieve an appropriate quality of poetic expression (Maras, "Pohrvaćivanje").

Badalić and Šoljan had to find a way to negotiate the different lexical capacities of English and Croatian lines, and so did Kazali, whose verse form is close to the English iambic pentameter in syllable number. Consequently, the original number of lines is preserved only in Maras's translation ${ }^{[14]}$ whereas Šoljan follows this principle in the first extract but increases line number in the second (by 13), as does Badalic in both (3.5 extra lines in the first extract and 29.5 in the second). This tendency is even more pronounced in Kazali's translation, which has, respectively, 43 (version A), 235 (B) and 24 (C) extra lines.

Regardless of their different choices of form, all Croatian translators found it necessary to modify to a certain extent Milton's specific treatment of punctuation, syntax, and lineation, and especially the high incidence of enjambments and long sentences encompassing a number of lines (Corns 41-44; Creaser, "The Line" 89; Creaser, "Prosody" 300). All translators had a tendency to divide such sentences into shorter independent units yet often followed the syntactic breaks in Milton's lines, particularly those (originally) marked by a colon and sometimes by a semicolon or a comma. [15] Notwithstanding such alterations, all four verse translations reflect Milton's tendency toward enjambments, although the degree to which they have managed to maintain this feature differs in each text, as does the overall treatment of the original syntactic and semantic makeup of individual lines. A short extract from Book 1 can help briefly demonstrate and compare their various approaches (it comprises the first five lines from the description of Satan and rebellious angels immediately after the fall):

Nine times the Space that measures Day and Night

To mortal men, he with his horrid crew Lay vanquisht, rowling in the fiery Gulfe Confounded though immortal: But his doom Reserv'd him to more wrath; for now the thought ... (1.50-54)Table 1. Maras's versionTable 2. Badalić's versionTable 3. Šoljan's versionTable 4. Kazali's translation

\begin{tabular}{|l|l}
\hline Maras's version & Literal English translation
\end{tabular} 


\begin{tabular}{|c|c|}
\hline $\begin{array}{l}\text { Devet je puta raspon što dan i noć mjeri } \\
\text { ljudima smrtnim, on, sa svojom groznom družinom, } \\
\text { pobijeđen ležao, valjajuć u ognjenom se ždrijelu, } \\
\text { uništen, premda besmrtan. Al njegova ga kob } \\
\text { za veću srdžbu sačuva; jer sada misao ... (1.50-54) }\end{array}$ & $\begin{array}{l}\text { Nine times the span that day and night measures } \\
\text { [to] men mortal, he, with his horrid crew/company, } \\
\text { vanquished/defeated lay, rolling in the fiery gulf, } \\
\text { destroyed, though immortal. But him his doom/fate } \\
\text { for greater wrath has (p)reserved; for now the thought }\end{array}$ \\
\hline Badalić's version & Literal English translation \\
\hline $\begin{array}{l}\text { I devet puta vr'jeme, kojim smrtnik } \\
\text { Dan i noć mjeri, s groznom četom svojom } \\
\text { Pobijen ležaše u struji ognja } \\
\text { Sav smeten, ali besmrtan; prokletstvo } \\
\text { Sačuvalo ga još za veći jad; } \\
\text { Pa sad ga misô ... (1.52-57) }\end{array}$ & $\begin{array}{l}\text { And nine times the time [span], [with] which a mortal } \\
\text { Day and night measures, with the horrid troop [of] his } \\
\text { [He] vanquished/beaten lay in the current [of] fire } \\
\text { All confused, but immortal; damnation/doom } \\
\text { (P)reserved him even for greater misery; } \\
\text { So now him the thought ... }\end{array}$ \\
\hline Šoljan's version & Literal English translation \\
\hline $\begin{array}{l}\text { Smrtničkih devet dana, noći, on se } \\
\text { Sa svojom strašnom četom k } \square \text { trljao } \\
\text { Ponorom plama, potučen i proklet } \\
\text { Premda i besmrtan. Al' sudbina mu } \\
\text { Pripremi veću kušnju; jer ga misli (1.50-54) }\end{array}$ & $\begin{array}{l}\text { Mortals' nine days, nights, he was } \\
\text { With his horrible troop rolling } \\
\text { [In] the abyss [of] flame, vanquished/beaten and damned } \\
\text { Though also immortal. But fate/doom [for] him } \\
\text { Has prepared a greater trial; for him the thoughts ... }\end{array}$ \\
\hline Kazali's translation & Literal English translation \\
\hline $\begin{array}{l}\text { VERSION A: } \\
\text { Devet krati vremena, što mjeri } \\
\text { Umrlimi dan i noć, on hrupne } \\
\text { Predobiven s grdom svojom vojskom } \\
\text { Orio se po užastnom jazu, } \\
\text { Kan zapanjen, prem da neumrli. } \\
\text { Al ga Udes većoj zržbi hrani: } \\
\text { Sad ga spomen ... (1.60-66) }\end{array}$ & $\begin{array}{l}\text { Nine times the time [span], that measures } \\
\text { [To] mortals day and night, he bursts [in] } \\
\text { Vanquished/overpowered with hideous his army } \\
\text { He was falling/collapsing through the dreadful chasm, } \\
\text { As if confounded/stupefied, though immortal. } \\
\text { But him Doom [for] greater wrath preserves: } \\
\text { Now him the memory ... }\end{array}$ \\
\hline $\begin{array}{l}\text { VERSION C: } 21581 \\
\text {... Devet krat vremena } \\
\text { Što umrlim dan i noć premjèra } \\
\text { Predobiven s gadnom družbom hrupne, } \\
\text { Te se valja u uzastnom jazu. } \\
\text { Sav zapanjen, prem da neumrli, } \\
\text { Dal ga Udes većoj sržbi hrani: } \\
\text { Sad ga spomen ... (1.61-67) }\end{array}$ & $\begin{array}{l}\text {.... Nine times the time [span] } \\
\text { That [to] mortals day and night measures } \\
\text { Vanquished/overpowered with the loathsome crew/company [he] bursts [in], } \\
\text { Then [he] rolls in the dreadful chasm. } \\
\text { All confounded/stupefied, though immortal, } \\
\text { If him Doom [for] greater wrath preserves: } \\
\text { Now him the memory ... }\end{array}$ \\
\hline
\end{tabular}

In accordance with his above-described general approach, Maras's translation is closest to the original, and it is the only one that retained the equivalents of almost all words and phrases within the same lines, as well as their exact position in four out of five enjambments. Still, even Maras does not follow this principle strictly in his entire translation, and sometimes departs from the original simply in order to balance line length, as some lines would otherwise be disproportionately long in Croatian rendering. As far as rhythm is concerned, the iambic intonation Maras strived for 
does not give the impression of a regular and prominent pattern, as it is not always as consistent nor easily perceptible, which makes his text, as a whole, rather close to rhythmized prose arranged in lines. Consequently, numerous individual phrases may be read both in accordance with the modern speech rhythm and with an imposed iambic pattern (resorting to [secondary stress] promotion and demotion).

The respective metrical frameworks in the other three translations demanded more variation in the distribution of words within and at the ends of lines, and sometimes even shortening or omitting the parts of content, as well as vowel elision. Such redistribution, as well as shortenings and omissions are already evident in the example of Badalić's version, although he does not refrain from occasional lexical additions either, especially if they can help sustain iambic rhythm (as in lines 52 [“i” = "and"], 55 ["sav" = "all”] and 56 [“još" = "even"] in his count). Šoljan modified the original to an even greater extent, but not without poetic effect. For instance, line 52 in the quoted extract is rather freely rendered, but with an effective use of assonance and alliteration ("Ponorom plama, potučen i proklet"), which, combined with rhythmical irregularity (dominant dactylic rhythm and four beats instead of five) adds a further dramatic touch to the image of the fallen Satan and his crew. Šoljan's treatment of the verse form is generally freer than Badalić's. Although there are a few irregular lines in the latter author's translation, he tends toward a more consistent iambic rhythm, employing, when necessary, common devices such as initial inversion and promotion of weak syllables or secondary stress. Even so, his lines seem more regular in comparison with Milton's original and its "paradoxical fusion of prosodic strictness and freedom" (Creaser, "Prosody" 299; Creaser, "The Line"). Badalić's lines are fairly regular in terms of syllable number as well, since they usually contain ten or more, often eleven, syllables (more common in Croatian because of its higher frequency of feminine endings). Still, there are exceptions - several longer (12-13 syllables) and (more numerous) shorter lines (8-9 syllables).

Badalić's verse is illustrative of the overall state of Croatian versification in the late 19th century, when the iambic pentameter and accentual versification were relatively new phenomena, the Croatian verse system having been predominantly syllabic until the late 1860s (Jurić 10). Their introduction helped establish new translation standards, and the creation and employment of Croatian versions of foreign verse forms, accentual and even quantitative. This early stage was 
marked by a tendency toward a more regular form of the iambic pentameter, which would go on to become one of the most dominant verse forms in the last decades of the 19th century (Juric 64-81; Kravar 196), even though iambic rhythm is not so natural in the modern standard Croatian due to its specific phonological and morphological features (e.g., general prohibition of final syllable stress, fewer monosyllabic words and larger average word length; Užarević 94-95).

The two parts of Šoljan's translation differ in this respect. All lines in the first part are isosyllabic (11 syllables) and are, as a whole, more metrically regular than the lines in the second part, which combines the 11-syllable basis with lines of various length, but therefore has fewer content omissions. Šoljan too resorts to the abovementioned metrical variations when needed, yet his translation is more varied than Badalić's and contains more lines with an initial beat as well as with a varying number of beats. This is consistent with the evolution of the Croatian hendecasyllabic verse (an equivalent to the iambic pentameter) in the 20th century, and its movement toward greater flexibility of rhythm (Kravar 173-216). At the same time, Šoljan's overall approach testifies to the fact that he was a (post)modern poet and translator, striving for an equivalent poetic effect, which licensed him to more freedom in the treatment of the original.

Kazali's substantial increase in line number has opened up even more space for the transmission and redistribution of the original content. Hence, he did not need to resort to its frequent or major omissions, although he did not refrain from its modification whenever he found it necessary or more convenient. Moreover, Kazali's lines are generally more syntactically rounded (end-stopped) than both Milton's and the other three translators'. This feature is typical of the (oral) asymmetrical decasyllable (so called as the caesura falls after the 4th syllable), which was originally based on a rather firm syntactic structure, with clear syntactic borders at line and semi-line ends (Kravar 58-60). In Kazali's time it had become more flexible, particularly in written poetry, and his usage of enjambments testifies to this fact as well; yet, the traces of its original syntactic makeup had not vanished from the overall 19th century literary and translation practices ${ }^{[17]}$ This type of syntax combines well with another feature typical of oral verse tradition - a rather high frequency of repetitive figures, which can partly account for Kazali's increase of the line number and the corresponding content amplification, especially when not based on the same or similar figures in the original, but added to it. 
Out of the five Croatian translations of Paradise Lost, Šoljan's and Maras's are undoubtedly closest to the contemporary audience, but even they offer two relatively different interpretations of Milton's text. Šoljan's translation is more apt in terms of the overall poetic effect, and it is more succinct, albeit not always accurate enough with regard to content. Although it is not completely free from minor oversights and mistakes either, Maras's text is more faithful to Milton's in terms of content, but it is closer to a prose paraphrase and sometimes more literal than necessary. Parts of Maras's text that are rather close to the original may at times even sound slightly odd or unnatural in Croatian. This can be acceptable inasmuch as his translation thus partly reflects Milton's elevated style and its similar effect on the modern English-speaking audience; however, Maras's overall strategy of closer adherence to the original has proved more effective in other aspects of his text. His line-for-line rendition conveys the specific structure and flow of Milton's lines rather well, and he has managed to retain some other stylistic features, particularly the various figures of repetition, including assonance and alliteration. Maras further poeticized his translation by interspersing it with elements of archaic diction, which is not uncommon in some of Maras' other translations, as well as in modern Croatian translations of older poetry in general (especially, for instance, of Italian medieval and early modern classics, Tomasović 165-248; I. Grgić 82-126). These elements are not dominant and provide a subtle archaic undertone, which will be discussed in more detail below. Badalić and Šoljan, too, aimed for an elevated style that could adequately represent Milton's, albeit without resorting to any specific archaizing strategy (a slightly archaic undertone contemporary readers may perceive in Badalić's text can primarily be ascribed to its greater distance in time $)^{[18]}$ Moreover, due to the brevity of the selected extracts, they were not able to fully convey all of Milton's distinctive stylistic features, even though they have been partially retained, sometimes again with modifications.

Kazali's translation was limited in a similar way, but his verse form originated in a poetic tradition with its own characteristic stylistic repertoire, whose traces are still visible in his text. In addition to the frequent use of repetitive structures, these include, for instance, occasional diminutives and some typical expressions, which also add folkloric resonance to Kazali's lines. All of these features, combined with the elements of the early modern Dubrovnik idiom, provide his translation with a perceptible archaic patina, which is not a mere retrospective evocation of these two linguistic and 
literary traditions, but an integral part of the author's style. While Kazali thus transformed and domesticated Milton's text to a greater degree than any of the three later verse translators, it should be borne in mind that such strategies of domestication were common in the Croatian translations of English and other European literatures during the 19th century (Kravar).

In this respect, his translation is comparable to Ivan Krizmanić's, which developed within another specific linguistic and literary tradition. This tradition, on the other hand, as well as the choice of prose instead of verse, distinguish Krizmanić's Raj zgubljen from all later Croatian renderings of Paradise Lost. This is how the above quoted extract from Book 1 sounds in his Kajkavian prose:

Nine times the Space that measures Day and Night

To mortal men, he with his horrid crew

Lay vanquisht, rowling in the fiery Gulfe

Confounded though immortal: But his doom

Reserv'd him to more wrath; for now the thought .... (1.50-54)Table 5. Krizmanić's translation

\begin{tabular}{|l|l|}
\hline Krizmanić's translation & Literal English translation \\
\hline $\begin{array}{l}\text { - Ono vreme, koje noč i dan vmertelnem ljudem razmerja, vre devet krat se je } \\
\text { ponovilo bilo od potlam, da on z svojimi ogrutnimi puntari obladan, ležal je vu } \\
\text { ognjeni glublini se valajuč, osramočen, ako i nevmertelen. - Ali obsuđenje } \\
\text { njegovo zderžava njega još na vnogo vekšu ljutost. - Ar sada ga muči } \\
\text { razmišlavanje .... }\end{array}$ & $\begin{array}{l}\text { - The time [span], which night and day [to] mortal men measures, already } \\
\text { the fiery deep ropling, disgraced, even though immortal. - But the doom [of] } \\
\text { his reserves him even for a much greater wrath. - For now him torments the } \\
\text { thinking .... }\end{array}$ \\
\hline
\end{tabular}

Since he was not bound by restrictions of verse, Krizmanić had enough space for additional explanation and content amplification in his entire translation, which he is more prone to than any of the verse translators. This tendency partly testifies to Krizmanić's difficulties in finding adequate equivalents for certain terms and expressions, which he was obliged to paraphrase, but partly also to his wish to make his text easier to comprehend for the potential audience. The same wish probably motivated him to omit some of the classical references and replace them either with more ordinary terms (e.g., "Stygian" = "peklenski” [“infernal]") or with an explanatory paraphrase (e.g., "with Atlantean shoulders" [2.306] = "s pleči neizmerno širokemi" ["with chest immeasurably wide"; Milton, Raj zgubljen 58]). Furthermore, Krizmanić added explanations to some of the classical references and other terms he retained but believed were unfamiliar to his audience - for example, the phrase "volatil Hermes" (3.603) is amplified into "poskočnoga Hermesa, iliti, nigdar mirno, živo srebro" ("volatile/jumpy Hermes, or, the never still, quicksilver", Milton, Raj zgubljen 97)! ${ }^{[19]}$ 
Out of the five existing Croatian translations of Paradise Lost, Krizmanić's is the most liberal in treatment of the syntactic makeup of Milton's lines. At the same time, it displays some typical (old) Kajkavian features that make its syntax rather convoluted from the viewpoint of the modern standard Croatian, and can hence be viewed as Krizmanić's own analogue to Milton's syntax, bearing in mind, moreover, that the old Kajkavian language was similarly influenced by Latin in this aspect, although German influence was equally important (Puhalo 283,286$)^{[20]}$ Such parallel is still only indirect and most probably unintentional, as Krizmanić used a language that was specific in its own way and allowed him to freely rearrange the original clauses and phrases when necessary and/or convenient.

While Krizmanić should undoubtedly be given credit for his (explicitly proclaimed) attempts to remain as close to the original as possible (Puhalo 283, 287), in comparison with Maras's, as the only other integral Croatian translation of Paradise Lost, his translation is less accurate in terms of both content and style. Nevertheless, it remains an important pioneering accomplishment, which was quite extraordinary for its time and place. Although it nowadays primarily belongs to literary and cultural history, once the linguistic barrier is overcome, it still presents an interesting read, where freer and amplified renderings of Milton's phrases may at times even seem easier to understand than Maras's literal renditions.

In addition to the discussed formal features of Croatian translations of Paradise Lost, its historical and cultural references also open up the question of the (im)possibility of its adequate transposition into the Croatian context, particularly in the two integral translations. A good case in point is, for instance, Milton's criticism of the Christian Church, and especially of the Roman Catholic Church, which has been the central religious institution in Croatian culture for centuries. Notwithstanding this fact, neither Maras nor Krizmanić, who was a Catholic priest himself, omitted nor modified the motifs and episodes that might be problematic from the Catholic viewpoint, including, among others, the description of the Paradise of Fools in Book 3 with its clear anti-catholic stance $(474-97){ }^{[21]}$ Yet, some of Milton's lexical nuances were lost here as well, such as a possible ironic reference to papal authority in the Latinate forms "pontifice" and "pontifical" used in the description 
of the bridge built by Sin and Death over the abyss of Chaos in Book 10 (Corns 90-91). They could only be rendered with the terms derived from the standard Croatian word for "bridge" = "most": "mostovnim" (adjective) for "pontifical" (10.313) and "mostovlje" (a rare collective noun) for "pontifice" (10.348) in Maras's translation, and "mostovinskem" (adjective) and "mosta" (merely “bridge") in Krizmanić's (Milton, Raj zgubljen 277-78) ${ }^{[22]}$

Explanatory notes function as an important tool for interpreting the literary, cultural, and historical references in Paradise Lost in both integral translations. Although they are not exhaustive but selective and generally informative, they can offer a good insight into Maras's and Krizmanić's individual understanding of Milton's text and the readerly expectations they aimed to meet in their translations. Maras's comments are printed in the form of footnotes and encompass several categories - Christian religion (mostly biblical quotes, allusions and references, and the criticism of the [Roman Catholic] Church), classical mythology and literature, later European literary tradition, (pseudo)scientific, geographical and historical references (including Milton's biography), and explanatory comments on the text itself. Notes from the first category are the most copious and can function as a relatively reliable guide to the religious background of Paradise Lost (Maras, "Notes" 9), especially since Maras made an effort to provide the relevant quotations from the modern standard Croatian translation of the Bible in numerous notes and to correlate them with the text of his translation when necessary and/or possible. Not all biblical references have been recorded, though, and while their full knowledge is by no means indispensable for average Croatian readers, they could have been glossed in some further portions of the text as well. Croatian readers might also notice one minor oversight - Maras defines the Book of Tobit (alluded to in 4.168-71) as apocryphal but fails to mention that this does not pertain to the Catholic canon, where it forms an integral part of the Old Testament (Maras, "Notes" 103).

Maras paid particular attention to Milton's allusions to and quotations from other segments of the European literary tradition, although again in a selective manner. After the Bible, the second most frequently mentioned source are Homer's epics (especially lliad and to a lesser extent Odyssey), followed by Virgil's Aeneid and Dante's Divina commedia. Maras thus primarily aimed to position Paradise Lost within the classical and Christian epic tradition, emphasizing its links with the canonical texts familiar to the Croatian audience. One text is nonetheless surprisingly missing 
here, especially given its long and rich reception history in Croatia - Tasso's Gerusalemme liberata . All possible links and analogies with the identified texts are not recorded either, and the same is true for other intertextual sources[ ${ }^{[23]}$

This aspect of Maras's translation can be linked - both directly and indirectly - with his occasional usage or archaisms, another important strategy that helps him position his rendition of Paradise Lost in relation to different literary traditions. Next to biblical style, most clearly evoked in the relevant quotations and allusions, Maras included several Homeric terms as general reminiscences of the ancient Greek epic tradition, borrowed (sometimes in a modified form) from the latenineteenth century Croatian translations of the Iliad and the Odyssey ${ }^{[24]}$ A number of terms and expressions recall the central Croatian literary tradition, but mostly in a broad sense, although some of the terms evoke more concrete connotations. For instance, the following two words, used in reference to Eve, are reminiscent of the early modern amorous discourse: "lijepost" (for "fair," instead of the modern noun "ljepota") and "ljubven" (for "amorous," instead of "ljubavni").

Krizmanić's explanations of less known words, names and terms, which are separated in an appendix (Krizmanić, "Kratko slovoredno spisavanje"), generally cover the same areas as Maras's notes, and consequently contain a number of entries on the same subjects. However, Krizmanić's glossary has a more pronounced didactic and encyclopaedic function than Maras's (Jembrih, "Ivan Krizmanić" 480) and is in this sense complementary to his in-text explanations and amplifications. The difference between his and Maras's approach is already evident in the fact that Krizmanić glossed a greater number of items, many of which are familiar to modern-day readers, but might have been unknown to his contemporaries, especially those less educated (there are entries on such terms as Adam, apostle, hallelujah, gospel, fairies or nymphs, as well as on the continents, various plants and animals, etc.).

Maras's notes are more concise and precise, while Krizmanić's tend to be longer and more explicative, albeit in some cases not (completely) correct ${ }^{[25]}$ Moreover, they can include additional information that is not so crucial for understanding Milton's text, as it might have been interesting from the 19th century (Croatian) perspective, such as the expansion and power of the British Empire, or the then current Ottoman rule, which are emphasized in a number of geographical entries. Illustrative domestic examples include, for instance, the note on "llirikum" ("Illyria"), where 
Krizmanić explains not only its primary and (here only) relevant meaning of the ancient toponym, but also mentions its more recent employment in the official designations of the parts of Croatian (and Slovene) territory under Napoleonic and later Austrian rule (Krizmanić, "Kratko slovoredno spisavanje" 380$)$.

On the other hand, Krizmanić paid less attention to Milton's literary allusions and quotations. He does mention some of his sources - mostly the Bible and classical mythology and literature - but only briefly, when explaining certain mythological, historical, or geographical facts. Even so, one entry is particularly important from this viewpoint, as it contains one of the earliest references to Shakespeare in Croatian culture (Filipović 86): in the note on "Ariel" as a "rebel angel," Krizmanić adds that the "renowned English poet Shakespeare counts him among aerial spirits" (Krizmanić, "Kratko slovoredno spisavanje" 358).

The analyzed aspects of the five translations of Paradise Lost were primarily selected as illustrative of the different strategies of its "inscription" (Venuti) into Croatian (literary) culture, which included not only losses and modifications of the original form and content, but also the different elements the five translators managed to transpose (more or less) successfully into the new context. In this way, the analysis opened up the more general question of how Milton's text was read in Croatian culture in different periods, and how it was adapted to the various aspects of its linguistic, literary, and cultural tradition. Each translation offered a specific solution to this complex issue, and in this way earned its own noteworthy position in Croatian literary and cultural history. Although the two modern translations - by Šoljan and by Maras - are currently the most authoritative and accessible to contemporary readers, the three earlier renderings are undoubtedly important in their own right, and especially as pioneering achievements - Krizmanić's as the first (integral) translation, Kazali's as the first one in verse, and Badalić's as the first one that retained the original verse form. Furthermore, while Krizmanić's and Kazali's marginal position may seem a disadvantage from the contemporary point of view, it makes their translations significant from a historical perspective, as they offer two examples of Milton's reception in less known contexts. On the other hand, the two newer renderings of Paradise Lost have some disadvantages of their own - among other things, Šoljan's is only fragmentary and sometimes treats the original content rather freely, whereas 
Maras's at times appears too close to the original, but without keeping the original verse form.

Viewed as a whole, all five translations thus provide a variety of possible interpretations of Milton's epic that can serve as a point of comparison and even as a corrective to each other in numerous aspects, which are still open for further examination. Finally, their analysis begs another important question and a desideratum for the (near) future - a possible integral Croatian translation of Paradise Lost composed in the equivalent verse form, that is, the Croatian blank verse.

\section{Works Cited}

Brlek, Tomislav. Pogovor. Izgubljeni raj, by John Milton. Translated by Mate Maras, edited by Tomislav Brlek, Školska knjiga, 2013, pp. 363-72.

Creaser, John. "Prosody." The Milton Encyclopedia, edited by Thomas N. Corns, Yale University Press, 2012, pp. 297-301.

Creaser, John. "The Line in Paradise Lost." The Cambridge Companion to Milton, edited by Louis Schwartz, Cambridge University Press, 2014, 81-93.

Corns, Thomas. Milton's Language. Blackwell, 1990.

Dukat, Vladoje. "Miltonov ‘Paradise lost’ u kajkavskom prijevodu Krizmanićevu.” Nastavni vjesnik, vol. 10, 1902, pp. 281-92, 419-32.

---, ed. Čitanka iz englesko-američke i skandinavske književnosti. Kr. hrv.-slav.-dalm. zem. vlada, 1903.

---, ed. "Krizmanićev prijevod 'Izgubljenoga raja."' Građa za povijest književnosti hrvatske, vol. 8, 1916, pp. 143-75.

Duran, Angelica, et. al, eds. Milton in Translation. Oxford University Press, 2017.

Eco, Umberto. Mouse or Rat? Translation as Negotiation. Phoenix, 2004.

Engelsfeld, Mladen. Hrvatski prevoditelji Shakespearea. Hrvatsko društvo kazališnih kritičara i teatrologa, 1989.

Engelsfeld, Mladen. "Kazalijev hrvatski ekvivalent za Shakespeareov stih." Književna smotra, vol. 101-102, 1996, pp. 9-13. 
Filipović, Rudolf. Englesko-hrvatske književne veze. Liber, 1972.

Grgić, Iva. Poetike prevođenja. O hrvatskim prijevodima talijanske poezije. Hrvatska sveučilišna naklada, 2009.

Grgić, Kristina. “Engleski književni kanon u povijestima hrvatske književnosti.” Komparativna povijest hrvatske književnosti. Zbornik radova XX. Književni kanon, edited by Cvijeta Pavlović et. al, Književni krug, Odsjek za komparativnu književnost Filozofskoga fakulteta Sveučlišta u Zagrebu, 2018, pp. 346-72.

Janković, Vidosava. P. A. Kazali kao književnik i prevodilac Šekspirova "Kralja Lira." Filološki fakultet, 1968.

Jembrih, Alojz. “Ivan Krizmanić i njegovo djelo.” Raj zgubljen, by John Milton. Translated by Ivan Krizmanić, transcribed and edited by Alojz Jembrih, Disput, 2005, pp. 449-97.

Jembrih, Alojz. "Rukopisni opus Ivana Krizmanića u kroatističkim istraživanjima 20. i 21. stoljeća." Marija Bistrica u doba Ivana Krizmanića - "tiho žarište" hrvatskog narodnog preporoda i Matice ilirske, edited by Snježana Husinec and Vedran Klaužer, Matica hrvatska, 2018, pp. 195-219. Jurić, Slaven. Rastućim skladom. Prodor stranih stihova u hrvatsko pjesništvo druge polovice 19. stoljeća. Hrvatska sveučilišna naklada, 2002.

Kravar, Zoran. Tema "stih." Zavod za znanost o književnosti Filozofskog fakulteta Sveučilišta u Zagrebu, 1993.

Krizmanić, Ivan. Predgovor. Raj zgubljen, by John Milton. Translated by Ivan Krizmanić, transcribed and edited by Alojz Jembrih, Disput, 2005, pp. 9-11.

Krizmanić, Ivan. "Kratko slovoredno spisavanje vseh, vu zgubljenom Raju zemelskom napervo dojdučeh i nekojem čtavcem mozibiti menje znaneh imen i rečih." Raj zgubljen, by John Milton. Translated by Ivan Krizmanić, transcribed and edited by Alojz Jembrih, Disput, 2005, pp. 349-426. Lewalski, Barbara. Introduction. Paradise Lost, by John Milton. Edited by Barbara K. Lewalski, Blackwell Publishing, 2007, pp. xv-xxix.

Lupić, Ivan. Shakespeare između izvedbe i knjige. Nakladni zavod Globus, 2010. 
Lupić, Ivan, and Bojana Schubert. Prvi hrvatski Shakespeare. Pučko otvoreno učilište "Dragutin Novak," 2016.

Maras, Mate. "Pohrvaćivanje Johna Miltona.” Vijenac, vol. 397, May 2009,

www.matica.hr/vijenac/397/pohrvacivanje-johna-miltona-3352/. Accessed 16 Sept. 2018.

Maras, Mate. "Notes." Izgubljeni raj, by John Milton. Translated by Mate Maras, edited by Tomislav Brlek, Školska knjiga, 2013.

Milton, John. Izgubljeni raj. Translated by Hugo Badalić. Pobratim, vol. 6, 1896, pp. 81-82; vol. 7 , 1896, pp. 97-98; vol. 8, 1896, pp. 113-14; vol. 9, 1897, pp. 129-30.

Milton, John. "Izgubljeni raj." Sto najvećih djela svjetske književnosti, edited and translated by Antun Šoljan, revised ed., Nakladni zavod Matice hrvatske, 1980, pp. 280-84.

Milton, John. Izgubljeni raj. Translated by Mate Maras, edited by Tomislav Brlek, Školska knjiga, 2013.

Milton, John. Paradise Lost. Edited by Barbara K. Lewalski, Blackwell Publishing, 2007.

Milton, John. Paradise Lost. Edited by Alastair Fowler, 2nd ed., Routledge, 2013.

Milton, John. Raj izgubljen(i). Translated by Antun Kazali. Ms. 7556/19-4. Archive of the Serbian Academy of Sciences and Arts, Historical Collection, Antun Kazali's bequest, Belgrade.

Milton, John. Raj zgublyen. Translated by Ivan Krizmanić. Ms. R 3561. National and University Library, Zagreb, 1827.

Milton, John. Raj zgubljen. Translated by Ivan Krizmanić, transcribed and edited by Alojz Jembrih, Disput, 2005.

Novak, Slobodan Prosperov. Povijest hrvatske književnosti. Knjiga 3: Od Gundulićeva "poroda od tmine" do Kačićeva "Razgovora ugodnog naroda slovinskoga" iz 1756. Antibarbarus, 1999.

Puhalo, Dušan. Milton i njegovi tragovi u jugoslavenskim književnostima. Filološki fakultet, 1966.

Schubert, Bojana. U suton kajkavskoga književnog jezika. Povijesnosociolingvistička analiza jezika Ivana Krizmanića. Srednja Europa, 2016.

Slamnig, Ivan. Svjetska književnost zapadnoga kruga. 3rd ed., Školska knjiga, 2001. 
Strojan, Marjan. "Milton in Illyria." Milton in Translation, edited by Angelica Duran et. al., Oxford University Press, 2017, pp. 381-94.

Šoljan, Antun. "Pisac kao prevodilac i prevodilac kao pisac." Sloboda čitanja: Eseji, by Šoljan. Grafički zavod Hrvatske, 1991, pp. 119-48.

Šrepel, Milivoj. "Milton i Preradović.” Vienac, vol. 2, 1885, pp. 30-31; vol. 3, 1885, pp. 42-46; vol. 4, 1885, pp. 58-59; vol. 5, 1885, pp. 76-79; vol. 6, 1885, pp. 92-95.

Štebih Golub, Barbara. “Kajkavski hrvatski književni jezik u 17. i 18. stoljeću." Povijest hrvatskoga jezika. Knjiga 3: 17. i 18. stoljeće, edited by Radoslav Katičić and Josip Lisac, Croatica, 2013, pp. $221-61$.

Štebih Golub, Barbara. “Kajkavski hrvatski književni jezik u 19. stoljeću.” Povijest hrvatskoga jezika . Knjiga 4: 19. stoljeće, edited by Josip Lisac et al., Croatica, 2015, pp. 113-57.

Tomasović, Mirko. Traduktološke rasprave. Zavod za znanost o književnosti Filozofskog fakulteta Sveučilišta u Zagrebu, 1996.

Toury, Gideon. "The Nature and Role of Norms in Translation." The Translation Studies Reader, edited by Lawrence Venuti, Routledge, 2004, pp. 198-211.

Užarević, Josip. “Prema teoriji pjesničkog prevođenja.” Književna smotra, vol. 91, 1994, pp. 90-97. Venuti, Lawrence. Translation Changes Everything: Theory and Practice. Routledge, 2013. Warnke, Frank J. Versions of Baroque: European Literature in the Seventeenth Century. Yale University Press, 1972. 
[1] For an overview of the overall reception of anglophone authors in Croatian culture and its main body of research, see, e.g., Filipović; K. Grgić.

[2] Milton was already known in the late 18th and early 19th centuries in the erudite circles of Dubrovnik, but this fact did not play a notable role in his later reception (for more details see Strojan 383).

[3] The notion of translation policy is here used in the sense proposed by Gideon Toury, as referring to "those factors that govern the choice of text types; or even of individual texts, to be imported through translation into a particular culture/language at a particular point in time. Such a policy will be said to exist inasmuch as the choice is found to be non-random" (Toury 202).

[4] Translations from Croatian are by the author of this article. Specific stylistic and semantic nuances have been kept in the back translations of Paradise Lost if they were found relevant for analysis or illustrative of different translation strategies, but sometimes also neutralized if they impeded understanding.

[5] Both Šoljan's and Venuti's approaches are also comparable to Umberto Eco's notion of translation as negotiation between the original text and its receiving language and culture, which places emphasis on the functional equivalence rather than on the vague notion of "faithfulness" in translation (see Eco)

[6] Marjan Strojan's overview is generally informative and encompasses the translations of Paradise Lost in all South Slav cultures, although it does not mention Kazali's and Šoljan's translations.

[7] For Krizmanić's translation see Dukat, "Miltonov 'Paradise lost,"” Puhalo 280-87, and for Badalić's see Puhalo 292-95.

[8] Krizmanić returned to the manuscript of his translation in the following years as well, adding some further information to the foreword and the notes (Krizmanić, Predgovor 11; see also Jembrih, "Ivan Krizmanić" 475-76; Strojan 384). Although the editorial afterword to its printed edition praises it as the first prose translation of Paradise Lost in world literature (Jembrih, "Ivan Krizmanić" 485, 493; "Rukopisni opus" 214), this claim requires correction, as Krizmanić's version 
was preceded by several prose translations in different European cultures (see Duran et al.). A part of his translation (Book 2) was published in 1916 in modern transcription (Dukat, "Krizmanićev prijevod"144-75).

[9] To my knowledge, it was first mentioned as late as 1965 in the doctoral thesis by Vidosava Janković, reprinted in 1968 (Janković 8, 214-15, 225) and later referred to by Filipović (35). Interestingly, even the authors of the two overviews of Milton's reception in the former Yugoslav cultures (Puhalo; Strojan) seem to have been unaware of its existence, even though Dušan Puhalo recognized possible minor intertextual borrowings from Paradise Lost in Kazali's own dramatic poem Trista Vica udovica (332-35).

[10] The manuscript of Kazali's translation is stored in the Archive of the Serbian Academy of Sciences and Arts, and I owe special gratitude to the archivist, Mr. Borko Masalušić, for providing me with its photographic copy. The first and probably earliest version (see also Janković 214), henceforth version A, contains the translation of (the original) lines 1.1-220; the second and longest (henceforth version B) contains almost the entire Book 1 (1.53-798 and the translation of lines 1.644-47 - it was probably complete, as the first few pages are missing) and a part of Book 2 (2.1-237); the third (henceforth version C) is the shortest (1.1-103), and, judging by their similarities, it might be the beginning of a newer version of $B$ (which is evidently a working draft, with numerous corrections and some illegible lines). The manuscript includes eight additional pages (four pairs of linked pages), with translations of different extracts from Book 1 - two pairs present different versions of almost the same lines (95-128 and 96-127), while the other two contain the translation of the original lines 225-59 and 322-53.

[11] Since the extract from Book 1 is shorter in the later edition (original lines 1-49, and 1-51 in Badalić's count), Badalić's translation will be quoted from the first edition in the Pobratim magazine.

[12] The first edition of Šoljan's anthology, which came out in 1962 and was reissued five more times, contains only the excerpt from Book 1 (later also included in the popular textbook/anthology Čitanka iz stranih književnosti [Foreign Literatures Reader], edited by Nevenka Košutić-Brozović). Only the final and revised edition from 1980 contains both excerpts and will therefore be referred to in this analysis. 
[13] In his translation of Shakespeare's Collected Works Maras rendered the iambic pentameter with freely rhythmized lines that are described somewhat differently (as apparently being based on five stress-units), although their effect is not too dissimilar to that of the lines in Paradise Lost (see also Strojan 390; and for a critical analysis of Maras's verse form in the translations of Shakespeare see Lupić 202-07).

[14] Several lines have been omitted, but most probably by oversight, as their absence does not affect further line numeration.

[15] It should be noted that Krizmanić's punctuation has been partly modified in the modern transcript, where strong punctuation marks occur somewhat more frequently than in the manuscript. The analysis is based on Barbara Lewalski's edition of Paradise Lost (2007), which reproduces the original spelling and punctuation from the 1674 edition and is quoted throughout the article. The edition by Alastair Fowler (2013), which generally retains the original punctuation as well, has also been consulted. The overall problem of Paradise Lost's original punctuation (Lewalski xxxiii-xxxiv), as well as the fact that modernized English-language editions sometimes introduce stronger syntactic breaks in some of the abovementioned instances should not be overlooked here either, although only the two integral translations explicitly identify the editions of Paradise Lost their authors consulted. Maras's mentions four, both with the non-modernized and modernized punctuation and spelling. The punctuation and spelling in the edition Krizmanić used are partly modified/modernized, but Krizmanić's punctuation does not always follow this source either.

[16] These lines are missing in the version B.

[17] For the analysis of Kazali's similar employment of this verse form in the translations of Shakespeare's dramas see Janković 174-75; Engelsfeld, Hrvatski prevoditelji 119-63; Engelsfeld, "Kazalijev hrvatski ekvivalent".

[18] On the general impression given by Badalić's translation see also Strojan 387.

[19] For a more exhaustive list of Krizmanić's paraphrases and amplifications see Dukat, "Miltonov 'Paradise lost,'” 289-91; Puhalo 284-85. 
[20] One such feature is, for instance, a frequent usage of participial phrases and end-positioning of the verb in a sentence or a clause (see Dukat, 429-30; Štebih Golub, "Kajkavski hrvatski književni jezik u 17. i 18. stoljeću” 248-50; Štebih Golub, “Kajkavski hrvatski književni jezik u 19. stoljeću" 145-46).

[21] This fact accords with Krizmanić's more liberal views regarding the Catholic doctrine in general, and may have been one of the reasons why his translation was not immediately published (see Jembrih, "Ivan Krizmanić" 454, 470; "Rukopisni opus" 208, 213). Tendencies toward modifying or omitting the anti-Catholic elements have been documented in the translations of Milton's epic in other cultures with a strong Catholic tradition, such as Italy, Poland, Spain, Mexico or Colombia (see the relevant chapters in Duran et al.).

[22] The modern transcript actually has "mesta" ("place") on p. 278 , but this is a misprint, as the manuscript has "mozta" (i.e., "mosta"; see Milton, Raj zgublyen 155).

[23] These include Hesiod's Theogony, Sophocles's Oedipus the King and Antigone, Ovid's Metamorphoses, Lucretius's De rerum natura, Horace's poetry, La chanson de Roland, Ariosto's Orlando furioso and Shakespeare's Julius Caesar.

[24] Maras explicitly acknowledged his debt to this tradition in the note on the rare term "rtnik," employed as an equivalent to "Van" (army vanguard, 6.107; see Maras, "Notes" 163).

[25] One of the illustrative examples is provided by the note on Satan's "high Capital" in Hell, Pandemonium, Milton's coinage with the meaning of "all demons" or an "assembly of demons" (see e.g., Milton, Paradise Lost [2007] 34 and Milton, Paradise Lost [2013] 106, notes to the line 1.756). Krizmanić defines it in a broader and imprecise sense, relying on its etymology - as a pagan temple and a place of assembly in ancient Greece ("Kratko slovoredno spisavanje" 406). 